\title{
Stability of Unpasteurized and Refrigerated Orange Juice
}

\author{
Maria Cristina Corrêa de Souza ${ }^{1 *}$, Marta de Toledo Benassi ${ }^{2}$, Renata Fraxino de Almeida \\ Meneghel $^{2}$ and Rui Sérgio dos Santos Ferreira da Silva ${ }^{2}$ \\ ${ }^{1}$ Universidade Paranaense - UNIPAR; C. P. 224; 87502-210; Umuarama-PR-Brazil. ${ }^{2}$ Universidade Estadual de \\ Londrina-UEL; mcriscs@unipar.br; C.P.6001; 86051-970; Londrina-PR-Brazil
}

\begin{abstract}
The stability of orange juice obtained from a small extractor and stored in a polyethylene bottle was assessed under isothermal and non-isothermal storage conditions at 4,8 and $12^{\circ} \mathrm{C}$ for 72 hours. pH, titratable acidity and Brix did not alter significantly during the 72 hours storage. Microbiological analysis showed high initial count for moulds and yeasts that increased in the juice stored for $72 \mathrm{~h}$ under the non-isothermal conditions with temperature abuse $\left(12^{\circ} \mathrm{C} / 4 \mathrm{~h}\right)$. Date of the sensory evaluation showed a small reduction in product acceptance in this condition. The juice, in the recommended validity period (48h), presented losses of less than $20 \%$ of the initial ascorbic acid content regardless of the treatment. However, after this time, the degradation became accentuated reaching, at $72 \mathrm{~h}$ storage, retentions of 72 to $85 \%$.
\end{abstract}

Key words: Citrus fruit, shelf life, vitamin C, HPLC, sensory quality, moulds and yeasts

\section{INTRODUCTION}

Fruit juices are consumed for their characteristic flavor and are also considered sources of vitamins, minerals and soluble and insoluble fibers (Righetto et al., 1999). The citrus fruits have become a basic daily product in human nutrition and much consumption is attributed to the industrial use of other foods and drinks that require their flavor. There is a perspective of increase in the world orange production and a search for new markets for Brazilian juice in both the foreign and domestic markets (Lima et al., 2000).

Currently, the orange produced for industry is three times bigger than for in natura consumption (Agrianual, 1999). In search for greater practicality, the consumer market has shown growing interest in products 'ready to consume' (Lima et al., 2000). According to Pupin et al.
(1998), the internal retail market for orange juice in Brazil is based mainly on the trade of the natural product, refrigerated and packed in plastic bottles. However, there are few studies on an effective quality control for natural unpasteurized orange juice (Gusi, 1998).

Natural juices, even kept under refrigeration, have a short shelf life (Charalambous, 1993). Citrus juice stability depends on the raw material, processing conditions, packaging material and storage conditions. These factors should cause microbiological, enzymatic, chemical and physical alterations that damage the sensorial and nutritional characteristics (Corrêa Neto and Faria, 1999).

The sensorial aspect is directly related to consumer demand for the juice in the search for similarity to recently processed juice (Nisida et al., 1993). The alteration in natural juices intensifies continuously

\footnotetext{
* Author for correspondence
} 
after extraction, resulting in the development of undesirable flavor and color (Roig et al., 1996).

Microbial growth in citrus juice is characterized by the production of unpleasant flavors and product deterioration who is commonly caused by yeasts (Parish, 1991; Lima et al., 2000). Several authors have observed that flavor quality in citrus fruits was maintained as long as sanitization and storage temperatures appropriate to the product were used (Fellers, 1988; Tocchini et al., 1993; Nisida et al., 1993; Pao et al., 1996). Coloring and flavor indicate fruit ripeness (Salunkhe and Kadam, 1995) thus several physical and chemical determinations ( $\mathrm{pH}$, total soluble solid content and total titratable acidity) are important for orange juice characterization and quality (Nisida et al. 1993). Besides the chemical alterations, vitamin loss caused by temperature increase and/or oxidation reduce product acceptance (Charalambous, 1993). The ascorbic acid content represents a stimulating factor for citrus fruit consumption (Lee and Coates, 1987).

Thus the present study was carried out to study the chemical, sensorial and microbiological stability of unpasteurized orange juice in isothermal and non-isothermal storage, studying higher storage temperatures than those usually used and reassessing the recommended $48 \mathrm{~h}$ shelf life.

\section{MATERIAL AND METHODS}

\section{Juice extraction and storage}

Samples of commercial unpasteurized natural orange juice, Pêra Rio orange variety, obtained in a small-size FMC extractor and stored in $500 \mathrm{~mL}$ high density polyethylene package were used. After extraction, the samples were stored for $72 \mathrm{~h}$ under different conditions. In one of the programs, juice samples were stored under three isothermal conditions $\left(4^{\circ} \mathrm{C}, 8^{\circ} \mathrm{C}\right.$ and $\left.12^{\circ} \mathrm{C}\right)$. In the other, the temperatures were variable during storage with two different programs, and under condition $\mathrm{n}^{\mathrm{o}} 2$ the product was exposed to $12^{\circ} \mathrm{C}$ for 4 hours (Table 1). The samples were characterized for ascorbic acid contents and complementary physical and chemical analyses, sensorial and microbial analyses were applied only to those stored under non-isothermal conditions.

Table 1 - Program of the temperature conditions for sample storage.

\begin{tabular}{l|r|r}
\hline \multirow{2}{*}{ TIME $(\boldsymbol{h})$} & \multicolumn{2}{|c}{${\text { STORAGE TEMPERATURE } \boldsymbol{~}^{\circ} \boldsymbol{C} \text { ) }}$} \\
\cline { 2 - 3 } & ${\text { condition } \mathbf{n}^{\mathbf{0}} \mathbf{1}}^{\mathbf{c}}$ & 4 \\
4 & 4 & 8 \\
8 & 8 & 12 \\
$12 / 72$ & 4 & 8 \\
\hline
\end{tabular}

\section{Ascorbic acid determination}

The ascorbic acid content was detected in a liquid chromatographer with a spectrophotometric detector $(254 \mathrm{~nm})$. The analysis was performed at room temperature on a reverse phase Spherisorb ODS-2 column, isocratic elution $(0.7 \mathrm{~mL} / \mathrm{min})$ with sulfuric acid solution $\mathrm{pH} 2.5$ as mobile phase. Identification was carried out in the chromatograph based on the eluted solute retention in the column compared with the standard and using co-chromatography. The ascorbic acid was quantified by external standardization in duplicate (Souza, 2001).

\section{Complementary physical-chemical analyses}

The total titratable acidity (TTA), total soluble solid content (TSS) and $\mathrm{pH}$ were tested using the standard AOAC methodology (1995) in duplicate.

\section{Microbiological assessment}

Salmonella, the Most Probable Number of Fecal Colliforms and the Moulds and Yeasts were counted, according to the current legislation (Ministério da Saúde, 1998) for the samples under non-isothermal storage conditions by the Speck methodology (1976).

\section{Sensorial Evaluation}

The general acceptance test was applied, with 48 panelists, using the structured nine point hedonic scale where: $1=$ dislike extremely; $5=$ neither like nor dislike; $9=$ like extremely. The samples were served in transparent plastic glasses at a temperature around $7^{\circ} \mathrm{C}$ and $10^{\circ} \mathrm{C}$ in volumes of approximately $80 \mathrm{~mL}$. Two randomized samples were served sequentially per session. 


\section{RESULTS AND DISCUSSION}

\section{Ascorbic acid determination}

Fig. 1 illustrates a standard chromatogram used to determine ascorbic acid in orange juice.

There was considerable vitamin $\mathrm{C}$ retention. Even first order kinetics commonly used to model ascorbic acid degradation during various processes (Heldman and Lund, 1992) did not seem suitable to describe the phenomenon, when storage under the temperatures used was considered (up to $12{ }^{\circ} \mathrm{C}$ ) for the $48 \mathrm{~h}$ period (Fig. 2).

It was found that the product, in the recommended validity period (48h), presented losses of less than $20 \%$ of the initial ascorbic acid content, regardless of the treatment. In the samples maintained under isothermal conditions, ascorbic acid retentions of 80 and $86 \%$ were observed after $48 \mathrm{~h}$, depending on the storage temperature. Degradation was accentuated after this time, reaching retentions of 72 and $74 \%$ at $72 \mathrm{~h}$ storage (Fig. $2 \mathrm{a}$ ). The retention percentage was higher for samples under nonisothermal conditions, but similar behavior was observed: high retention until $48 \mathrm{~h}$ (98 to 100\%) and fast degradation after this period (80 to $85 \%$, in $72 \mathrm{~h}$ ) (Fig. 2b). This behavior demonstrated that the temperature did not seem to have been determinant as long as it remained in the range study.
The final ascorbic acid content after $72 \mathrm{~h}$ storage varied from 41 to $46 \mathrm{mg} / 100 \mathrm{~g}$. When these data were compared with the current legislation (Brasil, 1974) it was observed that they were superior to the $38 \mathrm{mg} \%$ referred to as minimum for industrialized juice. Taking into account that the Recommendation Dietary Allowances for ascorbic acid as 60mg/day for adults (RDA, 1989) and examining the results of the natural juice in question, it was found that the ingestion of $150 \mathrm{~mL}$, under any storage condition, would surpass the daily recommended per capita allowance.

\section{Complementary Physical and Chemical Analyses}

Similar results were observed for the data in the literature and the legislation for commercial juice (Brasil, 1974; Fellers, 1988; Tocchini et al., 1993; Nisida et al., 1993). The TTA values obtained were superior to the reference values, while the TSS/TTA ratio was low, possibly due to the variation in seasonalness and fruit ripeness. These parameters practically did not alter throughout storage, regardless of the temperature conditions used. Table 2 shows the variations in the means for $\mathrm{pH}$, TSS, TTA and TSS/TTA during the $72 \mathrm{~h}$ period, under isothermal and non-isothermal storage conditions.

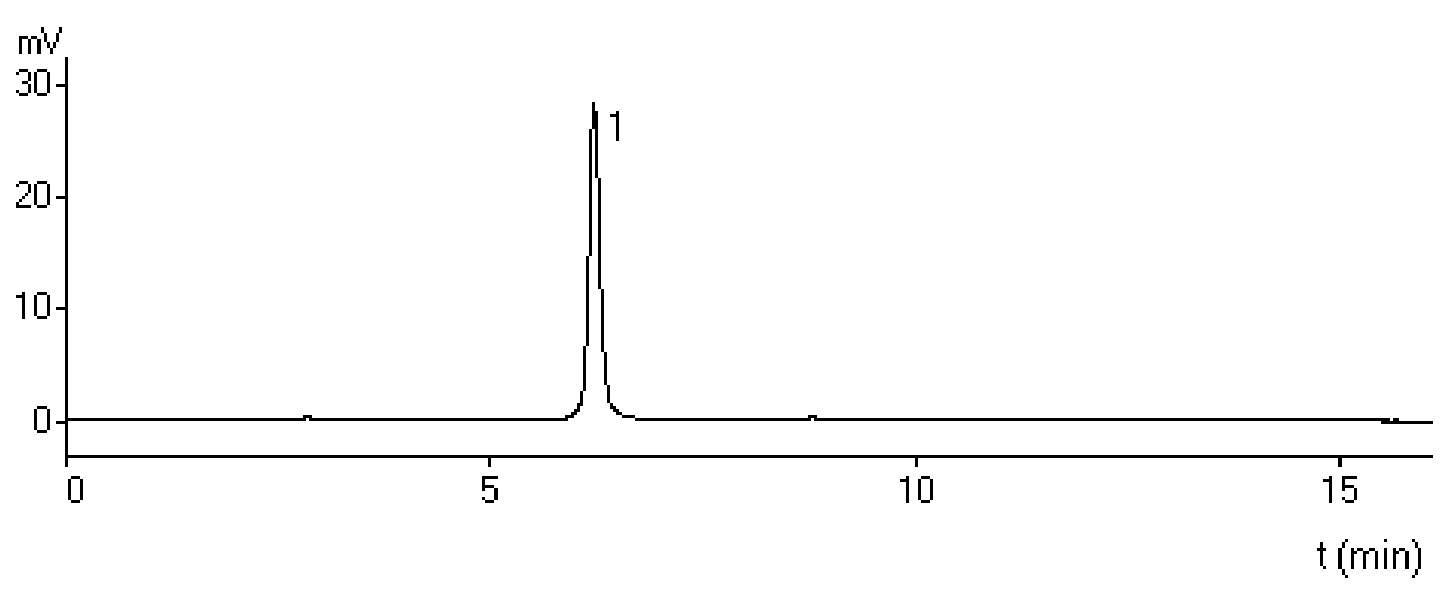

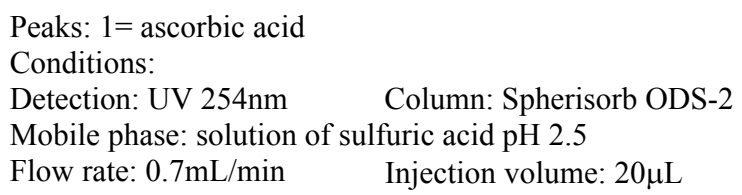

Figure 1 - Chromatogram of orange juice for the analysis of ascorbic acid. 


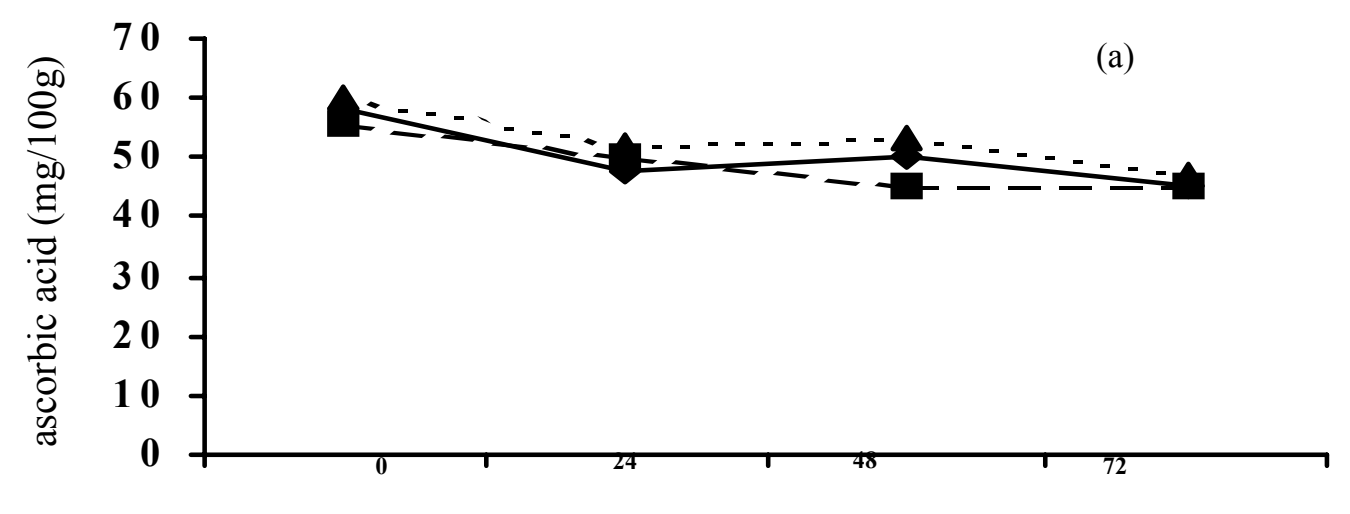

$\operatorname{tim} e(h)$
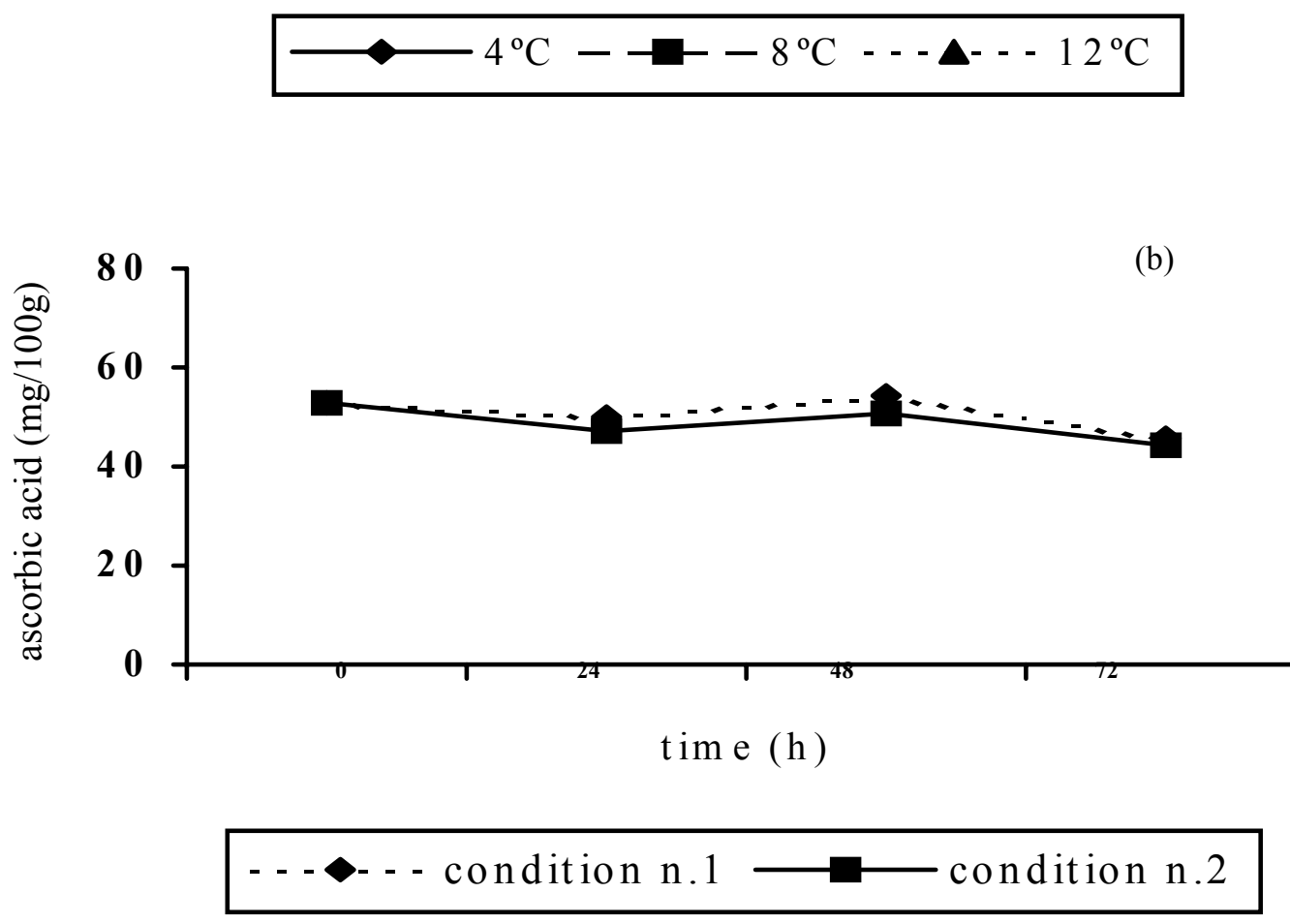

Figure 2 - AA concentration $(\mathrm{mg} / 100 \mathrm{~g})$ in natural orange juice stored under isothermal conditions (a) and non-isothermal (b) conditions (condition $\mathrm{n}^{\circ} 1-4 \mathrm{~h} / 8^{\circ} \mathrm{C}$ and $60 \mathrm{~h} / 4^{\circ} \mathrm{C}$; condition $\mathrm{n}^{\circ} 2-4 \mathrm{~h} / 4^{\circ} \mathrm{C}, 4 \mathrm{~h} / 12^{\circ} \mathrm{C}$ and $\left.64 \mathrm{~h} / 8^{\circ} \mathrm{C}\right)$.

\section{Microbiological assessment}

There was no Samonella and zero count for the fecal colliform group. The initial mould and yeast values detected were higher than those recommended by the current legislation (Ministério da Saúde, 1998) shown in Table 3. When the moulds and yeasts were examined separately there was a high yeast count that increased under the two storage conditions studied. The mould count in the juice stored under condition $\mathrm{n}^{\mathrm{o}} 2$ was higher then in condition $n 1$, probably because of the temperature increase to which the samples under condition $\mathrm{n}^{\circ} 2$ were submitted. The results, with high initial yeast count, may have been due to contamination of the fruit during harvest or re-contamination during processing. 
Table 2 - Assessment of unpasteurized refrigerated orange juice stored under isothermal and non-isothermal conditions for 72 hours.

\begin{tabular}{|c|c|c|c|c|c|}
\hline \multirow{2}{*}{$M E A N S$} & \multicolumn{3}{|c|}{ ISOTHERMAL CONDITIONS } & \multicolumn{2}{|c|}{ NON- ISOTHERMAL CONDITIONS } \\
\hline & $4^{0} \mathrm{C}$ & $8^{\circ} \mathrm{C}$ & $12^{\circ} \mathrm{C}$ & $\mathbf{n}^{0} \mathbf{1}$ & $\mathbf{n}^{0} 2$ \\
\hline $\mathrm{pH}$ & $3.24 \pm 0.02$ & $3.27 \pm 0.02$ & $3.30 \pm 0.02$ & $3.27 \pm 0.05$ & $3.28 \pm 0.03$ \\
\hline TSS ( ${ }^{\circ}$ Brix $)$ & $10.43 \pm 0.36$ & $10.55 \pm 0.28$ & $10.54 \pm 0.28$ & $10.54+0.28$ & $10.52 \pm 0.26$ \\
\hline TTA ( $\%$ citric acid $)$ & $2.20 \pm 0.06$ & $2.17 \pm 0.08$ & $2.12 \pm 0.04$ & $1.97 \pm 0.09$ & $2.02 \pm 0.13$ \\
\hline TSS/TTA & $4.75 \pm 0.26$ & $4.88 \pm 0.25$ & $4.98 \pm 0.15$ & $5.36 \pm 0.36$ & $5.22 \pm 0.35$ \\
\hline
\end{tabular}

TSS=total titratable acidity; TTA=total soluble solids; TSS, TTA and $\mathrm{pH}$ : mean of the values at time $0,24,48$ and $72 \mathrm{~h}$; condition $\mathrm{n}^{\circ} 1-4 \mathrm{~h} / 8^{\circ} \mathrm{C}$ and $60 \mathrm{~h} / 4^{\circ} \mathrm{C}$; condition $\mathrm{n}^{\circ} 2-4 \mathrm{~h} / 4^{\circ} \mathrm{C}, 4 \mathrm{~h} / 12^{\circ} \mathrm{C}$ and $64 \mathrm{~h} / 8^{\circ} \mathrm{C}$.

Table 3 - Microbiological results for a period of $72 \mathrm{~h}$.

\begin{tabular}{|c|c|c|c|}
\hline & Time $(h)$ & Condition $n^{\circ} 1$ & Condition $n^{\circ} 2$ \\
\hline Salmonella $\mathrm{sp}$ & 4 & Negative & Negative \\
\hline \multirow[t]{3}{*}{ (in $25 \mathrm{~mL})$} & 24 & Negative & Negative \\
\hline & 48 & Negative & Negative \\
\hline & 72 & Negative & Negative \\
\hline \multirow[t]{4}{*}{ Colliform fecal } & 4 & Zero & Zero \\
\hline & 24 & Zero & Zero \\
\hline & 48 & Zero & Zero \\
\hline & 72 & Zero & Zero \\
\hline \multirow[t]{4}{*}{ Mould (CFU/mL) } & 4 & $5.0 \times 10^{1}$ & $1.5 \times 10^{1}$ \\
\hline & 24 & $2.0 \times 10^{1}$ & $3.0 \times 10^{1}$ \\
\hline & 48 & $2.5 \times 10^{1}$ & $3.5 \times 10^{1}$ \\
\hline & 72 & $1.5 \times 10^{1}$ & $4.5 \times 10^{1}$ \\
\hline & 4 & $2.0 \times 10^{3}$ & $6.6 \times 10^{3}$ \\
\hline \multirow{3}{*}{$(\mathrm{CFU} / \mathrm{mL})$} & 24 & $7.8 \times 10^{3}$ & $6.2 \times 10^{3}$ \\
\hline & 48 & $1.5 \times 10^{4}$ & $8.9 \times 10^{3}$ \\
\hline & 72 & $2.7 \times 10^{4}$ & $1.8 \times 10^{4}$ \\
\hline
\end{tabular}

Condition $\mathrm{n}^{\circ} 1-4 \mathrm{~h} / 8^{\circ} \mathrm{C}$ and $60 \mathrm{~h} / 4^{\circ} \mathrm{C}$; condition $\mathrm{n}^{\circ} 2-4 \mathrm{~h} / 4^{\circ} \mathrm{C}, 4 \mathrm{~h} / 12^{\circ} \mathrm{C}$ and $64 \mathrm{~h} / 8^{\circ} \mathrm{C}$.

Table 4 - Mean scores obtained for the general acceptance test using the nine point structured hedonic scale.

\begin{tabular}{l|c|c|c|c}
\hline \multirow{2}{*}{ STORAGE CONDITION } & \multicolumn{4}{|c}{ MEAN SCORES/STORAGE TIME } \\
\cline { 2 - 5 } & INITIAL & $\mathbf{2 4 h}$ & $\mathbf{4 8 h}$ & $\mathbf{7 2 h}$ \\
\hline CONDITION n $^{\circ} 1$ & 7.2 & 7.0 & 6.8 & 6.8 \\
CONDITION n $^{\circ} 2$ & 7.2 & 6.6 & 6.8 & $6.0^{*}$ \\
\hline
\end{tabular}

*Significant statistical difference at the level of $5 \%$ by the Tukey Test. Condition $n^{\circ} 1-4 \mathrm{~h} / 8^{\circ} \mathrm{C}$ and $60 \mathrm{~h} / 4^{\circ} \mathrm{C}$; condition $n^{\circ} 2-$ $4 \mathrm{~h} / 4^{\circ} \mathrm{C}, 4 \mathrm{~h} / 12^{\circ} \mathrm{C}$ and $64 \mathrm{~h} / 8^{\circ} \mathrm{C}$.

Table 5 - Analysis of sensorial data by the Friedman test $(\mathrm{N}=48$ and $\mathrm{GL}=6)$ with the sum of the orders in decreasing order.

\begin{tabular}{l|c|c}
\hline \multicolumn{1}{c}{ TREATMENT } & MEAN ORDENATION & SUM OF THE ORDERS \\
\hline Time Zero & 4.7188 & $226.5^{\mathrm{a}}$ \\
24h (cond. $\mathrm{n}^{\mathrm{o}}$ 1) & 4.2708 & $205.0^{\mathrm{a}}$ \\
48h (cond. $\mathrm{n}^{\mathrm{o}}$ 2) & 4.1771 & $200.5^{\mathrm{a}, \mathrm{b}}$ \\
72h (cond. $\mathrm{n}^{\mathrm{o}}$ 1) & 4.1563 & $199.5^{\mathrm{a}, \mathrm{b}}$ \\
48h (cond. $\mathrm{n}^{\mathrm{o}}$ 1) & 3.9375 & $189.0^{\mathrm{a}, \mathrm{b}}$ \\
24h (cond. $\mathrm{n}^{\mathrm{o}}$ 2) & 3.8021 & $182.5^{\mathrm{a}, \mathrm{b}}$ \\
72h (cond. $\mathrm{n}^{\mathrm{o}}$ 2) & 2.9375 & $141.0^{\mathrm{b}}$ \\
\hline
\end{tabular}

Sum of the orders with the same letters indicates that there was no significant difference $(\mathrm{p}<0.05)$. 


\section{Sensorial Analysis}

The mean scores of general acceptance of the samples varied from 7.2 (like moderately) in the initial time to 6.0 (like slightly) under condition $\mathrm{n}^{\circ}$ 2 at $72 \mathrm{~h}$, this condition where the juice was submitted to temperature abuse being stored at 12 ${ }^{\circ} \mathrm{C}$ for 4 hours. The acceptance of the sample in the $\mathrm{n}^{\mathrm{o}} 2$ condition at $72 \mathrm{~h}$ differed significantly from the others at the level of $5 \%$ by the Tukey test (Table 4).

The results of the sample assessment at time zero and storage under the non-isothermal condition at times 24, 48 and 72 hours and submitted to the Shapiro-Wilks (W) test (Pimentel Gomes, 1985) for normality were all significant, rejecting the hypothesis of normal distribution (Statsoft, 1995). When the non parametric Friedman test was applied (Pimentel Gomes, 1985) the experimental data showed that the samples at time zero and $24 \mathrm{~h}$ under $\mathrm{n}^{\circ} 1$ condition presented greater acceptance than the samples at time $72 \mathrm{~h}$ under condition $\mathrm{n}^{\circ} 2$ that could be proved by the ordering of the sum of the R orders in Table 5.

\section{CONCLUSIONS}

In the present study, the samples presented good ascorbic acid retention (72 to 85\%) under isothermal and non-isothermal conditions up to the $72 \mathrm{~h}$ assessment. The final contents varied from 41 to $46 \mathrm{mg} / 100 \mathrm{~g}$, superior to the reference for industrialized juice $(38 \mathrm{mg} / 100 \mathrm{~g})$. Other parameters such as $\mathrm{pH}$, total titratable acidity, total soluble solids and the TSS/TTA ratio did not appear significant variation. The initial mould and yeast count exceeded than that permitted by legislation. As the initial contamination of the product was higher for yeast, this suggested that the raw material and/or its processing required better sanitary care. The juice kept under condition $\mathrm{n}^{\mathrm{o}} 1$ even at $72 \mathrm{~h}$ storage, did not differ from the recently processed juice in the acceptance test used, and acceptance was only reduced when there was temperature abuse (condition $\mathrm{n}^{\mathrm{o}} 2$ ). It would be possible to recommend an increase in natural orange juice validity from 48 to 72 hours if the initial yeast count was controlled.

\section{RESUMO}

Desenvolvimento microbiano, ação enzimática e reações químicas influenciam a qualidade de suco de laranja natural não-pasteurizado, podendo comprometer características sensoriais e provocar perdas nutricionais. A estabilidade do suco, obtido em extrator de pequeno porte e acondicionado em embalagem de polietileno, foi avaliada em condições isotérmicas e não-isotérmicas de armazenamento em temperaturas entre 4 e $12^{\circ} \mathrm{C}$ por $72 \mathrm{~h}$. Valores de $\mathrm{pH}$, acidez titulável e sólidos solúveis totais não se alteraram significativamente ao longo do armazenamento em todas as condições. Resultados da análise microbiológica mostraram alta contagem inicial de bolores e leveduras, que aumentaram no suco armazenado por $72 \mathrm{~h}$ na condição não isotérmica onde houve abuso de temperatura $\left(12^{\circ} \mathrm{C}\right.$ por $4 \mathrm{~h}$ ). Os testes sensoriais mostraram uma pequena redução na aceitação do produto nessa mesma condição. Constatou-se que o suco, no período preconizado como prazo de validade (48h), apresentou perdas inferiores a $20 \%$ do teor inicial de ácido ascórbico, independentemente do tratamento. A partir deste momento, a degradação se acentuou, chegando, com $72 \mathrm{~h}$ de armazenamento, a retenções de 72 a $85 \%$.

\section{REFERENCES}

Agrianual 99 (1999), Anuario da Agricultura Brasileira. FNP Consultoria and Comércio. Editora Argos Comunicação. 521 pp.

AOAC (1995), Official methods of analysis. Association of Official Analytical Chemists, Washington, D.C. pp. 16-17.

Brasil. Ministério da Agricultura (1974), Portaria $n^{\circ}$ 371 de 19 de setembro de 1974. Complementa padrões de identidade e qualidade para suco de laranja. Diário Oficial [da República Federativa do Brasil], Brasília, 19 de setembro.

Brasil. Ministério da Saúde. (1998), Portaria no 451 de 19 de setembro de 1997. Diário Oficial [da República Federativa do Brasil], Brasília, 22 de setembro.

Charalambous, G. (1993), Shelf life studies of foods and beverages. Amsterdam : Elsevier Science. 253 pp.

Corrêa Neto, R. S. and Faria, J. A. F. (1999), Fatores que influem na qualidade do suco de laranja. Ciência e Tecnologia de Alimentos, 19 : (1), 153-160.

Fellers, P. J. (1988), Shelf life and quality of freshly squeezed, unpasteurized, polyethylene-bottled citrus juice. Journal of Food Science, 53, 1699-1702.

Gusi, L. D. (1998), Estudo das cadeias produtivas do agronegócio paranaense - laranja. [S. 1. : s. n.]. 
Heldman, D. R. and Lund, D. B. (1992), Handbook of Food Engineering. New York : Marcel Dekker. $756 \mathrm{pp}$.

Lee, H. S. and Coates, G. A. (1987), Liquid chromatographic determination of vitamin $\mathrm{C}$ in commercial Florida citrus juice. Journal of Micronutrient Analysis, 3, 199-209.

Lima, V. L. A. G.; Mélo, E. A. and Santos, L. S. (2000), Avaliação da qualidade de suco de laranja industrializado. Boletim CEPPA, 18, : (1), 95-104.

Nisida, A. L. A.; Tocchini, R. P.; Berbari, S. A. G.; Alves, R. M. V. and Porto, E. (1993), Estabilidade de suco de laranja não-pasteurizado, armazenado a $4^{\circ} \mathrm{C}$. Coletânea do ITAL, 23 : (2), 173-180.

Pao, S.; Fellers, P. J.; Brown, G. E. and Chambers, M. W. (1996), Formulation and sensory evaluation of fresh-squeezed, unpasteurized citrus juice blend. Fruit Processing, 7, 268-271.

Parish, M. E. (1991), Microbial concerns in citrus juice processing. Food Technology, 45 : (4), 128-134.

Pimentel Gomes, F. (1985), Curso de Estatística Experimental. 11. ed. Piracicaba : Nobel. 466 pp.

Pupin, A. M.; Dennis, M. J.; Parker, S.; Kelly, S.; Bigwood, T. and Toledo, M. C. F. (1998), Use of isotopic analyses to determine the authenticity of brazilian orange juice (Citrus sinensis). Journal of Agriculture Food Chemistry, 46, 1369-1373.

RDA (1989), Food and nutrition board, National Research Council, National Academy of Sciences: Recommended Dietary Alowances. $10^{\text {th }}$ ed. Washington, DC : National Academy Press.

Righetto, A. M.; Beleia, A. and Ferreira, S. H. P. (1999), Physicochemical stability of natural or pre-sweetened frozen passion fruit juice. Brazilian Archives of Biology and Technology, 42 : (4), 393-396.

Roig, M. G.; Bello, J. F.; Rivera, Z. S.; Lloyd, L. L. and Kennedy, J. F. (1996), Non-enzymatic browning in single- strenght reconstituted citrus juice in tetrabrik cartons. Biotechnology Program, 12, 281-285.

Salunkhe, D. K. and Kadam, S. S. (1995), Handbook of fruit science and technology. New York : Marcel Dekker. 611 pp.

Souza, M. C. C. (2001), Estabilidade de suco de laranja não-pasteurizado e refrigerado: determinação de ácido ascórbico por CLAE, avaliação microbiológica e sensorial. Londrina. Dissertação (Mestrado em Ciência de Alimentos) Departamento de Tecnologia de Alimentos e Medicamentos - Universidade Estadual de Londrina.
Speck, M. L. (1976), Compendium of methods for the microbiological examination of food. Apha American Public Health Association. 701 pp.

Statsoft (1995), Inc. Statistica for Windows - Computer program manual, Tulsa, OK.

Tocchini, R. P.; Nisida, A. L. A. and Berbari, S. A. G. (1993), Estabilidade do suco de laranja refrigerado, em condições definidas de distribuição e comercialização. Boletim SBCTA, 23, 128-132.

Received: July 02,2002 ; Revised: January 29, 2003; Accepted: December 22, 2003. 